\title{
Revitalization Of Historical Urban Parks Using A Smart Approach
}

\author{
Mona M. Abdelhamid
}

Department of Architecture, Pharos University In Alexandria, Canal ElMahmoudia Street, P.O. Box 37, Sidi Gaber, 21311 Alexandria, Egypt

\begin{abstract}
:
Urban Park can play a great role in providing the city with more sustainable environment. Large green areas contribute also in creating healthy living environment and increasing human productivity. Moreover, historical urban parks have cultural, social and economical values. However, many historical gardens are not in an active use especially in developing countries because of lack of maintenance and other fundamental aspects that meets different users needs such as safety, conformability and social activities. The revitalization cost of the historical public urban park makes a great pressure on the government especially in developing countries. Smart technologies can offer a good. The main objective of this research is to highlight the importance adopting the smart landscape approach and smart technologies in the revitalization program, as it may have the advantages of reducing pressure on the government for the garden development and maintenance. The research finally concludes with recommendations the importance of implementing smart park approach in the revitalization of historical urban parks to improve park efficiency, human conformability and develop sustainable tourism.
\end{abstract}

Key words: Historical gardens; landscape approach; smart parks; sustainable revitalization; Internet of Things

\section{INTRODUCTION}

Nowadays, the majority of cities suffers from overcrowding, rapid life style as well as noise, visual and air pollutions. Public urban parks can offers some relief from the congestion, squalor, psychological tension, ill health, etc.. However, sometime large congested cities can include untapped large open green spaces. Since, new technology occupied a big place in human modern life that helps people get easy access for new information, there is a need to understand how to make a healthy balance between using technology and enjoying outdoor recreational spaces [1]. The landscape is also a healthy environment as it helps in sustaining and restoring the biodiversity of different species and habitats that are connected to the natural environment. Large urban parks can contribute to ecological and sustainable urban development. Green spaces in cities have great benefits as they can provide air purification through $\mathrm{Co} 2$ sequestration and producing oxygen. They also can regulate the micro-climate and preserve the biodiversity. They also help in reducing noise in congested cities. Moreover, they provide recreational spaces that protect cultural and social values especially if they are historical parks [2]. The research first began by defining what are historical parks, urban parks, and the meaning of using landscape approach for parks development. Then, it introduces theoretical review about the main aspect that can lead to a successful rehabilitation process for the re-use of public urban parks. Three international examples of historical garden that have been revitalized will be analyzed according to the factor that leads to the successful and continues usage of the parks. The research explained that the conservations of historical gardens is a must for their survival, but, also inserting modern technologies in the revitalization of 
the park are important to support and facilitate the conservation process as well as attract the future generation to use the parks. The research aims to examine the recent developments of smart technologies and the Internet of Things Technologies (IoT) that might be used in the revitalization of Public Park and especially the unused historical gardens to enhance the achievement of long-term objectives of the Park Authority and its stakeholders.

\section{Literature Review}

\subsection{Development Of Urban Parks}

The term 'Park' was first used for the European royal gardens. However, there have been some royal parks that were opened to the public as early as the 17 century such as: Hyde Park in London [12]. In the earlier movement of urban park, green open spaces have only represented the form of rural landscape, but without regarding its ecological functions. Urban parks at this time were usually located at the outer limits of the cities and mainly used for recreational purpose [2]. The movement toward creating urban parks in large American and European cities begins in the 19th century with the rapid industrialization and the fast environmental degradation [13]. Victoria Park in England was the first form of urban park that was supported by the Brittan government [2]. The concept of designing urban parks was developed to have both ecological and recreational importance to meet community needs as well as to connect them with their natural environment rather than just providing a green space to observe [13]. Central and valuable lands in the cities were selected to house urban parks in order to create green spaces that help for stress relive inside the congested cities and to provide ecological solution as well. The open green areas have increased 55\% in public park area in Europe between 1976 and 1992 [15]. On one hand, many urban parks in developed countries are recently designed to integrate both environmental education with leisure and social activities. Energy efficiency and cradle-to-cradle concept have been adopted to create sustainable and ecological urban parks. This integration aims to create a strong connection between people and nature. This connection will gives people a great opportunity to re-start learning from nature to meet all their need and to design their environment using minimum resources and materials. This 'naturalistic' style, which is called at the present day as 'biommimcry' or 'bio-insiration' will definitely lead to a sustainable urban development [2]. On the other hand, there are several parks that already exist and represent a very good green asset in developing countries but, unfortunately, they are absolute.

\subsection{Defining of Historic Urban Public Parks and Gardens}

According to ICOMOS-IFLA document on historic urban public parks, historic urban public parks are green spaces that are accessible for all peoples with different social levels. A historic public park is the one who was built during the $19^{\text {th }}$ and $20^{\text {th }}$ centuries and sometimes may be older. The government typically controls them and there are one or more public bodies or public foundations that are responsible of parks care and maintenance. Historic urban parks have valuable landscape and hardscape elements such as old vegetation, water features, architectural elements, pedestrian paths, or topography and some times may include monumental structures. The continuous maintenance of these elements is important to preserve their original character and visual identity. Historic Urban parks have been used for events and activities as well as for social gathering time and relaxation. Many of them may have changes in their original design, vegetation, character, and uses [11]. 


\subsection{Defining Smart landscape approach}

People using the open space have always affected landscape design. Thus, landscapes should be modified to meet aesthetic and functional objectives of stakeholders. The terminology 'landscape approach' has been used widely to describe a more integrative approach to respond users needs. Smart landscape approach is used to preserve existing environmental assets and connecting this conservation with the socio-economic development. Landscape approach aims to achieve long-term improvements to conservation and revitalization of using urban space by involving the people who are affected in decision-making. Monitoring and post occupancy evaluation together with stakeholder's feedback can lead to a strong development program. The development program will have the flexibility to be change and modified according to the users feedback. The landscape approach is usually adopted when the local governments cannot bear alone the burden of the working across different sector to achieve a successful landscape development. In this case, institutions and multiple actors such as private sectors, civil society and international conservation NGOs seek to attain impact through influencing actor's decisions. However, the role local government is important in providing legitimacy. The landscape approach should be evaluated twice during the development process. First the effectiveness of identifying appropriate goals should be evaluated; and second evaluating the achievement of those goals. This process should be developed using a strong theory of change. The theory of change has to respect the urban context, social beliefs, rationales, and all other evidence that serve the analysis. The development of this theory needs a transparent conversation between wide ranges of stakeholders in order to achieve a full vision for the most appropriate future condition of the landscape. A theory of change can assume a framework for using new technologies and citizen science to improve the landscape performance [3]. Smart landscape approach can provide an easy access for accurate information related to human behavior within the urban space through connecting the open landscape space with a central network using WI-FI Internet technology.

\subsection{Encouraging Public Park Usage}

Public Urban Parks are places that help human being to interact with each other and to connect them with the surrounding natural environment. Providing large green spaces within the central part of the city are essential for enhancing the quality of human life and creating healthy environment. However, it is noticed that local citizens in many countries are not encouraged to use the existing public park. Thus, there are many aspects that should be provided at minimum to encourage the active use of public urban parks [4]. They include:

- Accessibility

- Comfortability

- Security

- Understanding users needs

- Social activities

- Inserting modern technologies

\section{a) Accessibility}

A successful urban public space should be accessible for people using different means of public and private transportations as well as for pedestrians especially who live around the neighborhood. Parking spaces for private cars can be provided in areas 
or multistory building near the park and then connected with safe pedestrian crosswalks and side walks. Planners should provide safe pedestrian movement from the houses in the surrounding area to the park. Providing public transit stops near the public garden entrance will enhance the accessibility level for a wide range of users coming from different distances. Fences or barriers that bound the park space should be light to provide visual access and sense of continuity [4].

\section{b) Comfortability}

Public open urban areas should provide comfortable seating near good views (water element and vegetation) for relaxation and reducing stress. Seating has to be shaded either by pergolas or seasonal trees to provide relief from the direct access of sun in summer and at the same time allowing visitors to enjoy the warm felling of sun in the winter. The park should also include comfortable pathways that are convenient and safe for all age groups and people with special needs. Informative signage is an important element that should be well distributed to provide comfortable circulation within the large area of the park. This will facilitate the way finding form any point to another within the garden space. Well-organized greenery with consistent colors is also desirable to raise the level of human satisfaction and comfortability. Regular maintenance for natural and man-made element presented in the site will avoid visual discomfort [4].

\section{c) Security}

Feeling insecure within a large open public space is the main cause of discouraging people to use the park. This felling can transform a pleasant green area to an abandoned place. Thus, safety is the most important aspect that can lead to a successful public park. Dark corners and hided spaces should be avoided to prevent crime, harassment and drugs injection or any other sort of violence [4].

\section{d) Understanding user needs}

Urban public parks should be designed, planned, and managed to meet different users needs. Thus, stakeholders should participate during the planning process of new public gardens or the revitalization of existing ones to help planners in realizing different users preferences and to unsure successful use of the park [4].

\section{e) Social activities}

Social Value has a great influence in encouraging community members to interact together [2]. Different social activities that respond to stakeholders needs are essential for attracting them to visit and enjoy their time in the park. Social activities can be represented in musical bands, fun or learning activities for kids, playing sports, walking, gymnastics, climbing, etc. The existence of specific landmark or a public art, monuments and different animals species within the urban park will encourage a wide range of people to discover a new experience. Thus, active engagement is an important aspect at will create a livable space trough different days of the week. It is important to study and determine different needs for the majority of user groups in order to choose the most reliable activities [4].

\section{f) Inserting modern technologies}

Modern life in cities is highly affected by using network technology. Many researches have reported that people are strongly connected with their cell phones, tablet and lap tops to finish their work or use social website to connect with each 
other. Smart Park tends to combine both new technology and outdoors social activities to revitalize the use of an existing urban park. Several studies have shown that people are more interested to visits places that have free Wi-fi Internet connection. Moreover, landscape planners and park manager can also benefit from this network technology, as they can get daily information about the number of visitors, duration of their stay and their location in the park. This information can be used to improve park design and determine a good schedule for social events and activities. For instance, if the data reported that lower visitor density is during the hot afternoon, then the decision of providing more shaded seating around a water element and schedule for kids water activity at that time will be the better solution to increase park visitation [1].

\section{Smart Parks Approach}

\subsection{Defining Smart Park}

Smart Park is defined as: An urban or national park that uses the new approach of smart technologies and the Internet of Things (IoT) in the park design and during operation time [5]. It is based on using both central control and citizen control of networked devices power and analyzing the received data to improve the functioning of the Park [5].

\subsection{Model of Smart Park}

There are 10 main key dimensions that can be used to measure the degree of obtaining a great design of Smart Park (See fig. 1) [5].

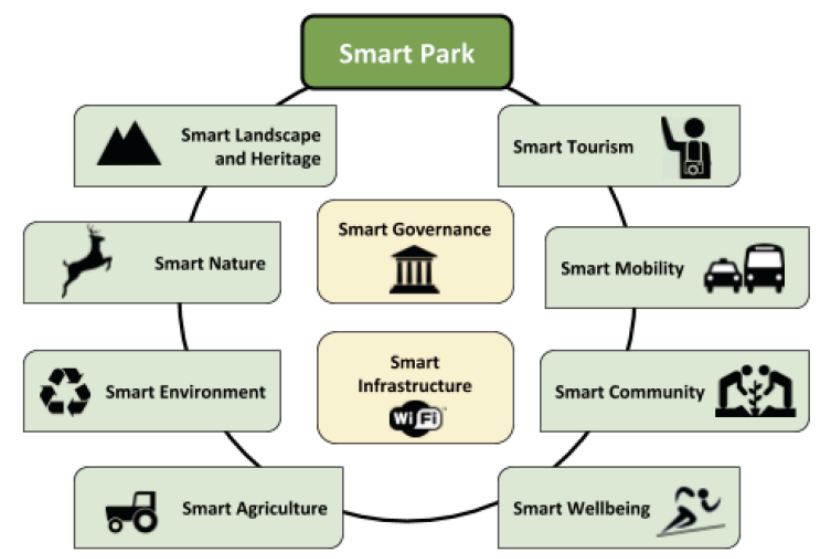

Figure 1: Smart park model and key dimensions. Source: E. Truch, J. Sutanto. 2018

\subsection{Benefits of Smart Parks}

The wide range of information exchange and the high degree of connectivity can lead to costs reduction, creating new income flow, improving environmental control, as well as enhancing visitors experiences and human well being [5].

\subsection{Smart Technologies}

While technology didn't play a major role in the historic park design, operation or development projects, advanced smart technologies are important to help park managers to overcome many problems. There are a variety of smart technologies that can be use to improve the lack of fund resources for park maintenance and improvement by conserving energy and water resources which will consequently reduce maintenance costs. These may include the following: 
a) Irrigation systems with "smart water controllers"

Determine the optimal amount of watering needed based on data collected through soil moisture and weather sensors. Weather data collected sensors may not be located at the park but it can be may be relayed wirelessly to the park's controller network via the Internet of Things (IoT). This smart irrigation system it adapted to daily, seasonal, and long-term changes in soil and climatic changes [6].

\section{b) Rainwater harvesting}

Rainwater harvesting tanks captures and stores rainwater for landscaping to provide a slow release into the soil, or other uses. Rainwater harvesting is not a new technology, but it can be connected to a smart irrigation system [6].

\section{c) Automatic lawn mowers}

Automatic lawn mowers are self-moving machines that are used to cut grass. The machine is controlled through programming, sensors or remotes. It uses battery that is charge via a charging base plugged into an electric outlet. The electricity may be driven from any source of clean energy such as solar energy. The robotic machine will reduce staff time and costs to maintain landscaping [6].

\section{d) Solar-powered trash}

Solar-powered trash compactors are used for waste recycling through crushing garbage by using source of clean energy. These containers remain closed all the times, which keep pests away. Sometimes these compactors have sensors that send alert when it becomes full and it is time to empty the bins. It could also be used as a source of Wi-Fi connectivity. In 2013, the City of Santa Clarita, California, have installed 34 solar powered trash and recycling compactors in parks. After 5 months of operation, the city noted that it is more efficient in collecting recycled material than other traditional recycling bins [6].

\section{e) Energy-generating exercise equipment}

This can includes cardio, toning, and strength training machines. Using these equipment will generate heat fro the friction, which is converted through a generator into electrical energy. This source of clean energy can be used directly do charge electronic devices or can be transmit to a central grid for other uses such as on-site lighting. The average amount of energy generated from these machines is 50 to 150 watts per hour depending on the fitness of the users [6].

\section{f) Smart benches}

Smart benches are multi-user seat that are solar-powered and contain USB-charging ports for electronic devices and some model are used as a source of Wi-Fi connectivity. These benches may have embedded sensors that can monitor useful information about parks such as pedestrian activity, air quality, temperature, and noise levels. They can also determine how many and how long visitors stay in the park and which area or activity is used more and have frequent usage. The collected data can be used to enhance the park performance by providing a better understanding of how visitors use different facilities. This can help park managers to offers new amenities and programs that reflect users needs [6].

\section{g) Motion-activated sensors for exterior lighting}

Motion-activated lights have sensors that detect motion via microwave or 
ultrasonic energy. They then send out a burst of energy to open the light. Motionactivated sensors do not guarantee safety and should be combined with other safety measures [6].

\section{h) Daylight fluorescent aggregate}

Daylight fluorescent aggregate is a kind of impervious paving used provide glowin-the-dark hardscape materials for pedestrian paths or for bicycles routes. The fluorescent pigments in the aggregate absorb and store natural in the morning and then emit that light at night. It need about 10 minutes of exposure to natural light to glow up for around 12 hours [6].

\section{i) Paving for hardscape}

Traditional hardscaping materials such as asphalt and concrete address common concerns on the environment as they cause urban heat island effect, lack of storm water infiltration and require ongoing maintenance. New technologies in materials such as cross-laminated timber; pervious paving; piezoelectric energy-harvesting tiles; self-healing concrete; transparent concrete; carbon upcycled concrete; and phototocatalytic titanium dioxide coating will have less harmufull impacts on the environment. They can provide energy saving and need less maintenance [6].

\subsection{The Internet of Things (IoT)}

A public park can benefit from the Internet of Thing technology by distributing a set of digital sensors within the area of the park. Those digital sensors can record, store and transfer wirelessly information concerning lighting, weather, air and water quality, motion, energy and resources consumption, etc. Several devices that are connected trough the (IoT) such as cameras, sensors, smart phones, digital identification tags and Wi-Fi equipment can send and receive different types of data such as text, audio, images and numbers. Online software will create a fast digital communication between users, park operators and the local government [6]. That means a large amount of information mutual exchange at the same time between people-to-things, and things-to-things networks [5]. This will require a strong Internet infrastructure such as secured websites, servers, and database management systems [6].

\subsection{Smart Park with The Integration of IoT Ecosystem}

According to (E. Truch, J. Sutanto, 2018), the eight key elements that can create a Smart Park will be described in figure 2. The eight elements are arranged in hierarchical layers. Devices are the first layer that begins by receiving and producing data. Layer two and three are that data which are transmitted and the connectivity channels used to send and receive the information using the Internet of Things platform. Layer four is the IoT platform, which contains multiple arrays of data centres that store and process the information. Layer five represents the set of solutions addressing specific requirements via software applications on various types of interactive display devices such as smart mobile and smart tablets. Layer six is the analytical techniques of the solutions to generate the best results using different modes of interactive display. Layer seven represents the cognition of the results that are used by people and computers propped by artificial intelligence to develop actionable ideas to help in decision-making. Layer eight is the organizational intelligence, which is responsible of enabling smart management for individual park organizations through creating a strong connection between stakeholders and people 
managing the park. It is the neural network that forms the artificial brain of the Smart Park [5].

\begin{tabular}{|c|c|c|c|}
\hline \multicolumn{3}{|c|}{ IOT Layers } & Elements \\
\hline 8 & Intelligence & 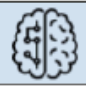 & $\begin{array}{l}\text { Park-wide organisational intelligence } \\
\text { Business model innovation } \\
\text { New revenue streams, new efficiencies }\end{array}$ \\
\hline 7 & Cognitive & & $\begin{array}{l}\text { Visualisation and management dashboards } \\
\text { Augmented (AR) and Virtual Reality (VR) } \\
\text { Reporting actionable insights }\end{array}$ \\
\hline 6 & Analytics & & $\begin{array}{l}\text { Data analytics } \\
\text { Aggregation from multiple data sources } \\
\text { Artificial intelligence (Al) }\end{array}$ \\
\hline 5 & Solutions & & $\begin{array}{l}\text { Process automation } \\
\text { Management Information Systems } \\
\text { Smartphone and desktop applications }\end{array}$ \\
\hline 4 & IOT Platforms & & $\begin{array}{l}\text { Park-owned or co-managed IOT platforms } \\
\text { 3rd party IOT platforms } \\
\text { Data storage and security }\end{array}$ \\
\hline 3 & Connectivity & & $\begin{array}{l}\text { Core Platforms \& Radio interfaces } \\
\text { Mobile networks such as NB-IOT, 3G, 4G, 5G } \\
\text { Open source mesh networks; LoRaWAN }\end{array}$ \\
\hline 2 & Data & & $\begin{array}{l}\text { Real-time data streams } \\
\text { Batched data feeds } \\
\text { Aggregation }\end{array}$ \\
\hline 1 & Devices & & $\begin{array}{l}\text { Sensors } \\
\text { Actuators } \\
\text { IOT Gateways }\end{array}$ \\
\hline
\end{tabular}

Figure 2: Smart park IoT Ecosystem. Source: E. Truch, J. Sutanto. 2018

\section{International Example of Historic Public Parks}

This section will discuss the history of three of international oldest public parks that have been revitalized after deterioration in different periods. Then, a comparative analysis will be made to examine the different levels in achieving the previously discussed aspect that encourage public park usage.

\subsection{Tiergarten: Berlin's Largest Inner-City Park, Germany}

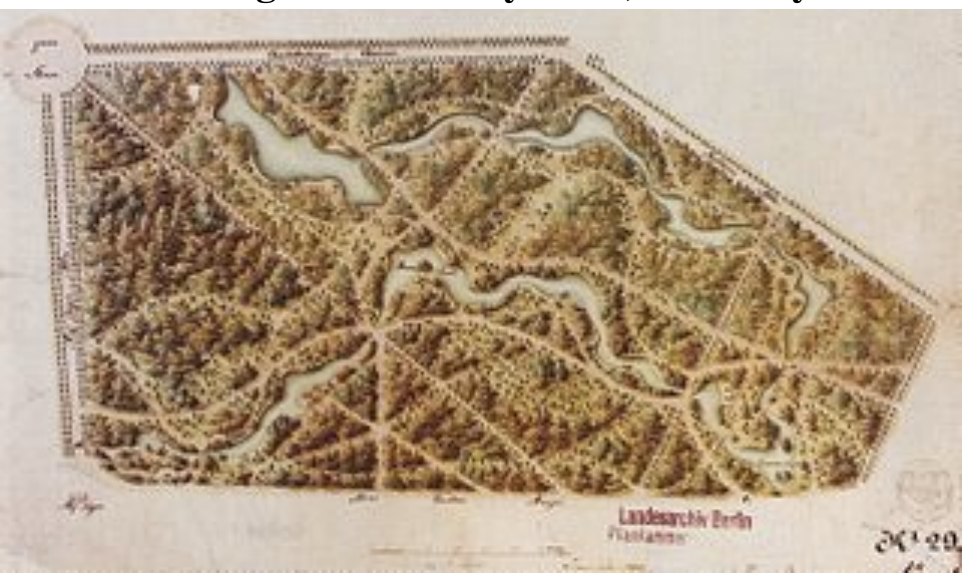

Figure 3: A park map of 1835 drawn by Peter Joseph Lenné Gerhard Koeber (1809-1852) Source: scan from periodical: Berlin in Geschichte und Gegenwart, 1989, p. 14.

The Tiergarten is the largest and oldest park in Berlin. It was listed as historical garden since May 1991 [8]. The green area of the garden covers 210 hectares. The garden attracts a wide range of visitors with different interests. People can enjoy different activities that have direct benefits on human health such as running, walking, skating, cycling, ball games and having family picnics while relaxing in the sun [9]. The garden were designed in the late $17^{\text {th }}$ century, when Friedrich III, then Elector of Brandenburg and Duke of Prussia have turned the royal hunting ground located 
outside the city into a large park to be a place of leisure for a wide range and categories of people. The Tiergarten Park has been re-designed several times, from 1833 till 1838. In this major makeover, it was Peter Joseph Lenné, Prussia's leading landscape gardener, who gave the park its final design that remains till today. This design was inspired from the English gardens models [9]. During the Second World War, Tiergarten Park was damaged. Huge areas of trees were cutting down to be used as source of fuel when berlin suffered from the lack of coal in winter of 1945-46 [9]. The historical garden was subjected to several renewals and restoration project since the early of 1980s in order to secure the park and save guard its ecological, traditional and cultural assets [8]. In 1949, the park was replanted with a lot of trees donation from all countries in Germany [9]. However, the Tiergarten has witnessed another phase of damage since 1996, when allowing the big-events that so-called "Love Parades" to take place in the Park. The "love Parades" is a famous electronic dance music festival that originated in 1989 in West Berlin, Germany. During this period around $10 \%$ of the total area has been destroyed because millions of people undertreated the historical park during the festival time [8]. The park was restored again and hosts a wide range of activities that serve the community. It contains also a number of historical monuments such as: Berlin's only surviving historical city gate the (Brandenburg Gate), the Soviet war memorial and the Victory Column (built 1864-1873) [9]. A part of the park was transformed to an open-air gas lantern museum for the revival of berlin's culture heritage. Gas lamps were used for street lighting earlier in berlin during 1826. Berlin hosts more than half of the survived gas street lamps of the entire world [10].

\subsection{Boulognerskogen Urban Park, in the Swedish city of Skövde}

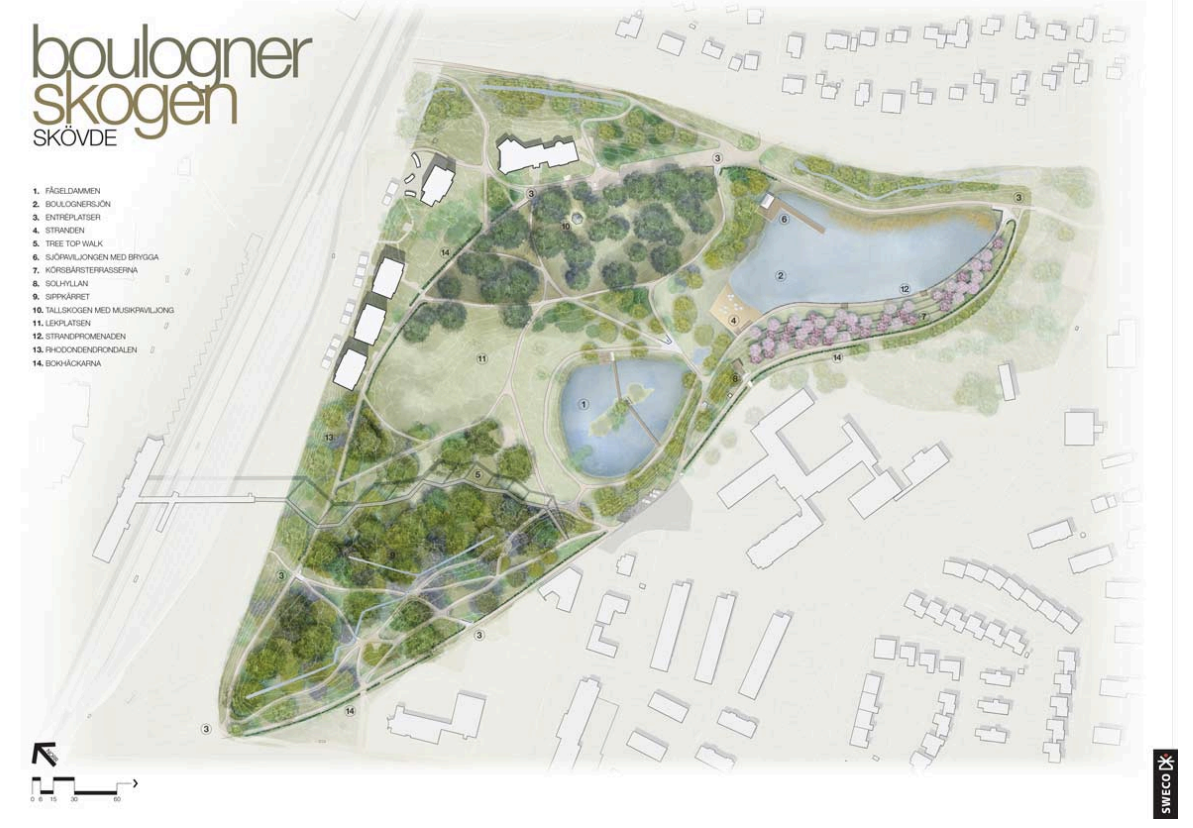

Figure 4: the winner design for the renovation of Boulognerskogen Park, in Skövde.

Source: landezine-award.com/boulognerskogen-restoration-of-an-historic-park/

The Boulognerskogen Park is centrally located in the city of Skövde covering an area of 14 hectares. Its topography has some levels and contains a variety of plant habitats, as well as a pond. The Park was first used as recreational ground for the higher society, later, for different social levels. Visitors came from all over the 
country during the mid of 19th century to enjoy the healthy spa water. At the beginning, the park was providing limited facilities such as a hotel and a restaurant that served mainly the upper class society [7]. During the 1930s the park facilities was changed to serve a wide range of working class. Several spaces were designed to meet community need such as: meeting and social gathering spaces, areas for sports facilities, spaces for parties and festivals. The artificial lake was constructed in 1933; it was used for skating during winter and for swimming in summer. However, the park fell into decay between 1960s and 1970s. The park became an unsafe place to go, many landscape features have been destroyed and the pond has been closed for swimming because of the poor water quality. The city of Skövde has lunched a competition to initiate the park revitalization through preserving some of the old values and combine them with new ones. The winner was the Landscape architect: Thorbjörn Andersson and PeGe Hillinge with Sweco architects. The duration of the design was 3 years from 2012 to 2014 and it was built in 2015. The revitalization program for the Boulognerskogen Park began with involving stakeholders to create the design program through inviting citizens into an open dialogue as well as active participation by the local politicians [7]. The result was the establishment of the following design:

- Seven new entrances were built to enhance people accessibility into the park.

- A viewing platform for elderly people was provided near their houses.

- Restoration of the artificial lake.

- Designing a sandy beach with a fountain to provide water circulation and freshness.

- Creating a pedestrian semi-shaded promenade along the beach shore.

- Designing of slope terraces for sun bath and was plated around with rows of multi stemmed cherry trees, Prunus sargentii.

\subsection{Lithia Park Ashland, Oregon, USA}

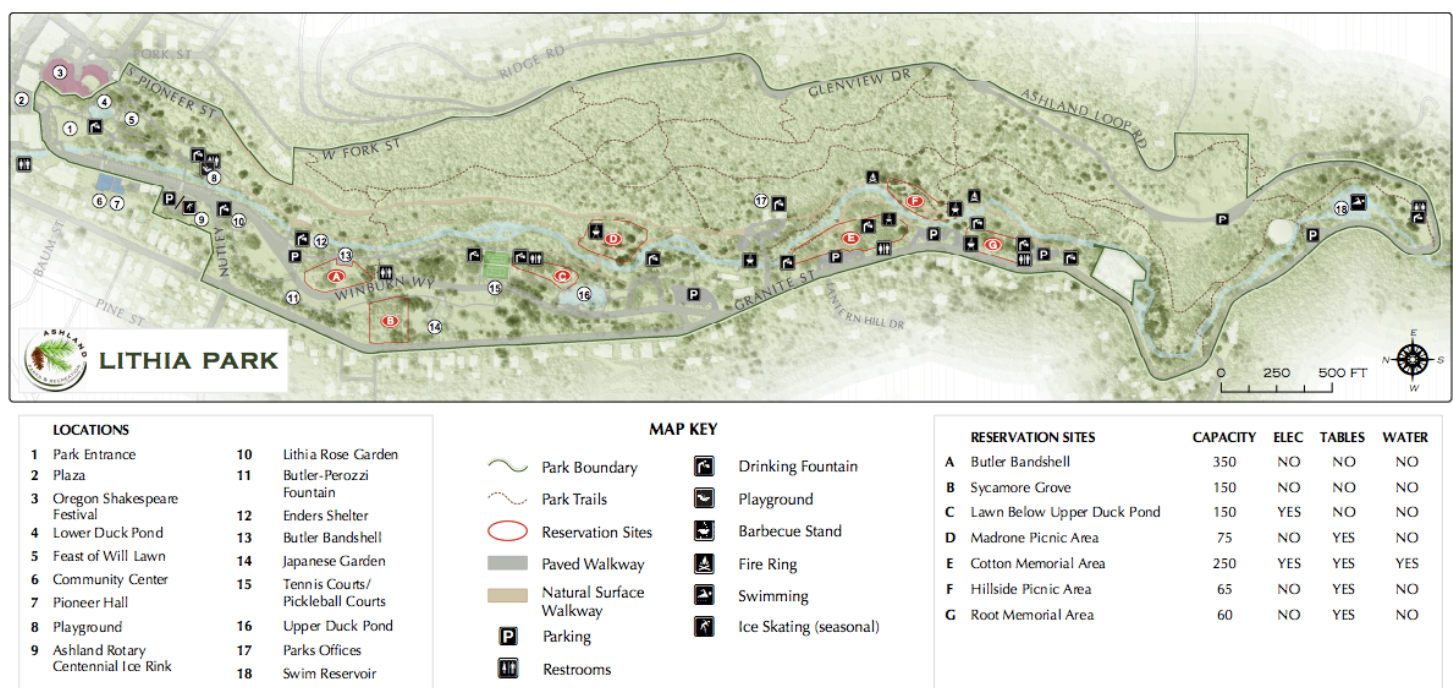

Figure 5: Map of Lithia Park Ashland, Oregon, USA.

Source: http://www.ashland.or.us/Files/Lithia_Park.pdf

The Lithia Park is located in the South of the downtown Ashland plaza and cover an area of encompassing 93 acres between Granite Street from the west and Pioneer Street from the east [16]. The history of the park began during the late 19th century with the Chautauqua movement. In 1890s, the Chautauqua Association occupied 8 acres of land along Ashland Creek for development to become the first park in southern Oregon [17]. In 1907, Lithium oxide water was found near the site, it was 
thought to provide positive health benefits for the park users. In 1908, the park was extended for nearly a mile and become bigger than before. In 1912, the Atkinson Memorial Bridge was built near children's playground. In 1914, the city has provided the park with lithium oxide water through a pipe system that cost $175,000 \$$. During that time, the landscape architect, John McLaren was hired by Ashland to design and develop the landscape plan for the lower 18 acres of the park [16]. The organic design of the Gentle paths and the curvilinear road that follows the natural terrain and was inspired by Frederick Law Olmsted. McLaren's plan has developed many green areas and plazas that provide places for strolling and for informal gatherings, these places includes two Duck Ponds, Bulter-Perrozi Fountain which was offered to the park in 1915 by Gwin Butler and Domingo Perozzi, the Enders Memorial Gazebo built in 1916, a rose garden, and a Japanese garden. Others sports facilities such as Tennis courts were added to encouraged many uses and active sports [16]. The construction of the designed plan began in 1914 and finished in July 1915 [17]. In 1935, the Oregon Shakespeare Theater was built to present two Shakespeare plays and in 1959, the current Elizabethan Stage designed by Richard L. Hay was built. Over the years, the park has passed through ups and downs. Flood in 1974, caused several damages throughout the park [16]. In 1979, it was decides to start many restoration projects to revitalize the park to restore its former glory [17]. In 1982, the National Register of Historic places, has listed 42 acres from the total park area A flood has attacked the park again in 1997. Citizens have supported the park repair and development by providing repeatedly funding to improve the park condition and to prevent future flood damage. In 2013, Atkinson Memorial Bridge and the Enders Memorial Shelter Gazebo have been restored at a cost of $\$ 50,000$ and $\$ 154,000$ respectively. In 2014, there have been a project aims to improve the water quality of the pond in order to allow Chinook salmon to swim in the park's streams [16]. Recently, the park is subjected to several restoration projects such as: the restoration of the Nature Play Area at North Mountain Park and The Butler-Perozzi Fountain. In the early 1900s, Antonio Frilli in Florence, Italy sculpted the fountain. It was completely restored in the 1980s and recently need funding for general repairs and vandalism damage. It is notable that the Ashland Parks Foundation as nonprofit Organization has lunched donation campaigns to provide funding for the park restoration projects and created a website to facilitated the funding payment. Most of these donations are tax-deductible [19]. In addition to the natural green spaces and sports activities, there are several events and programs that attract victors through different periods of the year. Among many festivals, the "Oregon Shakespeare Festival," is operated every year from February to early November. The Annual "Feast of Will Dinner and Performance," hosted by the Lions Club and Oregon Shakespeare Festival, that take place near the park entrance. There are also, weekly concerts in summer from mid of June to mid of August that are hosted by the Ashland City Band at the Butler Bandshell [16].

\section{4. Comparative Analysis Between the Three Historic Public Parks}

The following table will summarize and compare how did the previous historical parks sustain their continuity to be an open green spaces that attract different kind of visitors' overtime. The six factors that encourage public park usage, which have been explained previously in the literature review, will be used as guidelines. 
Table 1: comparison between the three historic parks. Source: the researcher.

\begin{tabular}{|c|c|c|c|}
\hline FACTORS & Tiergarten, Germany & $\begin{array}{l}\text { Boulognerskogen Park, } \\
\text { Sweden }\end{array}$ & Lithia Park, USA \\
\hline ACCESSIBILITY & $\begin{array}{l}\text {-it is the largest park located } \\
\text { in the centre of Berlin. } \\
\text {-The main street that leads } \\
\text { towards Tiergarten is } \\
\text { the Straße des 17. Juni. }\end{array}$ & $\begin{array}{l}\text { - Providing seven entrances in } \\
\text { the revitalized project has } \\
\text { increased park accessibility. }\end{array}$ & $\begin{array}{l}\text {-The park is accessible from } \\
\text { the Granite street in the west } \\
\text { and have one entrance. }\end{array}$ \\
\hline COMFORTNESS & $\begin{array}{l}\text {-Visitors feel confortable } \\
\text { when having a nice evening } \\
\text { stroll surrounded by } \\
\text { historical buildings and the } \\
\text { flowing water all around the } \\
\text { park. }\end{array}$ & $\begin{array}{l}\text {-Visitors felt comfortable } \\
\text { during the mid of the } 19^{\text {th }} \\
\text { century when they came from } \\
\text { all over the country to drink } \\
\text { the healthy spa water and cure } \\
\text { themselves with cold baths. } \\
\text { - The park was destroyed and } \\
\text { obsolete from } 1960 \text { till } 2011 \text {, } \\
\text { which make it uncomfortable } \\
\text { place. } \\
\text { - During } 2011 \text { till } 2015 \\
\text { citizen were involved in the } \\
\text { revitalization process, which } \\
\text { makes them feel comfortable } \\
\text { when using the park. The park } \\
\text { is now appreciated by many } \\
\text { of stakeholders and is used } \\
\text { for long walks, exercising and } \\
\text { picnics. }\end{array}$ & $\begin{array}{l}\text {-The organic design of the } \\
\text { Gentle paths and the } \\
\text { curvilinear road that follows } \\
\text { the natural terrain connect } \\
\text { people with their natural } \\
\text { environment. }\end{array}$ \\
\hline SECURITY & $\begin{array}{l}\text { - Currently, safe. } \\
\text { - It went trough ups and } \\
\text { downs especially during the } \\
\text { period of second world war. } \\
\text {-BBQ is not allowed in this } \\
\text { historical park due to safety } \\
\text { concerns and cleanliness. }\end{array}$ & $\begin{array}{l}\text { - The park was safe during the } \\
\text { middle of the } 19^{\text {th }} \text { century and } \\
\text { attracted visitors from all over } \\
\text { the country. } \\
\text { - The park felt into decay and } \\
\text { became an unsafe place to go } \\
\text { during between from } 1960 \text { till } \\
2011 \text {. } \\
\text { - With the revitalization of the } \\
\text { park in } 2015 \text {, it became safe } \\
\text { again and is now appreciated } \\
\text { by many of stakeholders who } \\
\text { use the park for several } \\
\text { activities such as: long walks, } \\
\text { exercising and picnics. }\end{array}$ & $\begin{array}{l}\text { - The park is occupied all } \\
\text { over the year, which means } \\
\text { that there is no security } \\
\text { problem. }\end{array}$ \\
\hline $\begin{array}{l}\text { UNDERSTANDIN } \\
\text { G USERS NEEDS }\end{array}$ & $\begin{array}{l}\text { - The garden attracts a wide } \\
\text { range of visitors with } \\
\text { different interests and } \\
\text { provide leisure place for a } \\
\text { wide range and categories } \\
\text { of people. }\end{array}$ & $\begin{array}{l}\text { - The park facilities were } \\
\text { changed several times to } \\
\text { serve a wide range of visitors. } \\
\text { - The revitalization program } \\
\text { of the park began with the } \\
\text { involvement stakeholders to } \\
\text { create the design program } \\
\text { through inviting citizens into } \\
\text { an open dialogue as well as } \\
\text { active participation by the } \\
\text { local politicians. }\end{array}$ & $\begin{array}{l}\text {-Citizens are involved in the } \\
\text { park repair and development } \\
\text { processes. }\end{array}$ \\
\hline $\begin{array}{l}\text { SOCIAL } \\
\text { ACTIVITIES }\end{array}$ & $\begin{array}{l}\text { - Sports activities: running, } \\
\text { walking, skating, cycling, } \\
\text { ball games. } \\
\text { - Social gathering: having } \\
\text { family picnics while } \\
\text { relaxing in the sun. } \\
\text {-"Love Parades" festival, } \\
\text { but, unfortunately it caused } \\
\text { damages in the park. } \\
\text { - Open-air museum for } \\
\text { historical Gas lamps. }\end{array}$ & $\begin{array}{l}\text { - Meeting and social } \\
\text { gathering spaces. } \\
\text { - Areas for sports facilities. } \\
\text {-The lake is used for } \\
\text { swimming in summer and ice- } \\
\text { skating in winter. } \\
\text { - Spaces for parties and } \\
\text { festivals. }\end{array}$ & $\begin{array}{l}\text {-Sports activities such as: } \\
\text { Tennis courts, pickle ball } \\
\text { courts, ice skating, swimming } \\
\text { pool. } \\
\text { - Community Centre. } \\
\text { - Playground. } \\
\text { - Several festival and events. } \\
\text { - Green spaces and plazas for } \\
\text { social gathering. }\end{array}$ \\
\hline $\begin{array}{c}\text { INSERTING } \\
\text { MODERN } \\
\text { TECHNOLOGIES }\end{array}$ & - None. & - None. & $\begin{array}{l}\text {-Internet website to facilitate } \\
\text { donation procedures. }\end{array}$ \\
\hline
\end{tabular}


The previous table has made a comparison between the three historical parks on how they attract visitors and how they have sustained their historical values over time. The table shows that the three historical parks have achieved five of the main factors that encourage public park usage with different levels. Inserting modern technologies was the only factor that wasn't achieved in the revitalization of the historical parks. It was only applied in the Lithia Park in Oregon with a very small intervention by creating a website that help and assist the government to provide the needed funding for the restoration projects. However, this aspect is becoming very important especially with development of cities and their need to become smart cities for the sustainable development. Smart Park can be a solution for many problems that currently exist in public parks ranging from underutilization by the public or park obsolescence, lack of fit with visitors needs, to diminishing resources, such as: funding needed for events, maintenance, and staff salaries [6].

\subsection{Smart Upgrades for Existing Historical Parks}

Some cities have tried to apply the concept of Smart Park as a part of a smart city development. For instance UCLA and California Department of Parks and Recreation (California State Parks) are working in developing smart technologies such as creating an interactive mobile website. This website will allow citizens living near the Los Angeles State Historic Park to provide content, such as digital murals, for the park that reflects the area's unique culture and history. Thus, considering the implementation of new technologies can help park managers directly engage with community groups to offer opportunities for local input in park design and programming that meet users needs and preferences [6].

Evaluating park benefits, considering the regional context and the neighborhood, identifying budget constraints, as well as, understanding the boarder planning process are the main aspects that should be determined by park managers before the adoption of new technologies [6].

\section{a. Examination of existing conditions and the infrastructure}

To have a good evaluation this aspect should be developed based on several interviews of park professionals and stakeholders. Identifying criteria for assessment such as accessibility, community integration, comfortability, security, etc. can be used as a guide to evaluate the effectiveness of parks in providing appropriate services [6]. Surveying of the existing infrastructure is essential to select the appropriate solution for its improvement.

\section{$b$. Considering the regional context and the neighborhood}

Park managers have to collect answers for several questions that relate their park with its neighborhood, local community and its region. What is unique in the park? Does it serve community needs? Is it connected with other parks around the neighborhood? From the answers, parks managers and decision-makers can find the most appropriate technologies that can fit in their park [6]. Surrounding communities should be engaged at each stage of the park development process (during the design process and in the operation time) to keep up-to-date on their particular needs and preferences for the ongoing park success. As an example, the Los Angeles Neighborhood Land Trust has creates community organizing team that is responsible of engaging the local residents during every stage of the park development to result with a creative park upgrading that reflect the local identity of the neighborhood [6].

M. E. Burstein in the book of "Smart Parks: A Toolkit" has developed some questions 
that could be used to guide decisions-makers in selection the appropriate technologies to upgrade park design considering community needs. These questions include: What are the demographics of the people living around the park(s)? What is their mother language or other spoken languages? Is the park accessible for children, adults, teenagers, and other people with limited mobility? What are the amenities that they need to have and use at the park(s)? How well does the park(s) serve its community? Is the community interested in family events, sports or education program? [6]

\section{c. The city planning process}

The development and upgrading of existing park will be efficient when it follows the city's long-term goals. For instance, it the city goal is to increase physical activity in the community, and then park managers can propose using technology such as energy-generating exercise equipment or interactive playgrounds. Other cities may have a wider goal of creating a Sustainable City and enhancing human comfort and general health. Such plans for environmental and sustainability initiatives will make park managers to include several technological upgrades (such as: Rainwater harvesting, Solar-powered trash, pervious paving etc..) in the planning process [6].

\section{d. Identifying budget constraints}

It is important to consider the funding strategies to start choosing the type of smart technologies that can be used in the rehabilitation process of the park according to their cost. Determining the park budgets and funding for capital upgrades and longterm maintenance is very important before taking any decisions about technology implementation. There are some small-scale technologies that can be considered because of their low initial costs and provide cost saving benefit in the long run and/or have multiple uses and benefits (See table 2)[6].

Table 2: Giving some examples for different scale of smart technologies:

\begin{tabular}{|c|c|c|c|c|c|}
\hline \multicolumn{2}{|c|}{$\begin{array}{l}\text { Small-scale technologies } \\
\text { having low initial costs }\end{array}$} & \multicolumn{2}{|c|}{$\begin{array}{l}\text { Technologies that provide } \\
\text { cost savings for } \\
\text { maintenance in the long- } \\
\text { term }\end{array}$} & \multicolumn{2}{|c|}{$\begin{array}{l}\text { Technologies that are cost- } \\
\text { saving because of their } \\
\text { multiple benefits }\end{array}$} \\
\hline $\begin{array}{l}\text { Solar } \\
\text { shades } \\
\text { and } \\
\text { umbrellas }\end{array}$ & $\begin{array}{l}\text { This will } \\
\text { provide shades } \\
\text { for visitors } \\
\text { while } \\
\text { providing } \\
\text { electricity } \\
\text { from a } \\
\text { renewable } \\
\text { energy for } \\
\text { powering } \\
\text { Electronic } \\
\text { devices. }\end{array}$ & $\begin{array}{c}\text { Smart } \\
\text { water } \\
\text { controllers }\end{array}$ & $\begin{array}{l}\text { Use weather and } \\
\text { site conditions } \\
\text { to automatically } \\
\text { adjust watering } \\
\text { to optimize } \\
\text { efficiency, } \\
\text { which can } \\
\text { reduce water } \\
\text { use and costs. }\end{array}$ & $\begin{array}{c}\text { Smart } \\
\text { benches }\end{array}$ & $\begin{array}{l}\text { They can provide } \\
\text { visitor tracking data, } \\
\text { solar-powered } \\
\text { device charging, and } \\
\text { Wi-Fi hotspots. }\end{array}$ \\
\hline $\begin{array}{l}\text { Pervious } \\
\text { paving }\end{array}$ & $\begin{array}{l}\text { It has several } \\
\text { benefits such } \\
\text { as: water } \\
\text { conservation, } \\
\text { safety, and } \\
\text { reduce } \\
\text { maintenance } \\
\text { cost }\end{array}$ & $\begin{array}{c}\text { Applying } \\
\text { photocataly } \\
\text { tic titanium } \\
\text { dioxide } \\
\text { coating }\end{array}$ & $\begin{array}{l}\text { Adding this } \\
\text { coating to } \\
\text { different } \\
\text { surfaces in } \\
\text { parks can lower } \\
\text { maintenance } \\
\text { costs over time } \\
\text { as it reduces the } \\
\text { need to clean } \\
\text { surfaces. }\end{array}$ & $\begin{array}{l}\text { Sensor } \\
\text { networks } \\
\text { and the } \\
\text { Internet of } \\
\text { Things }\end{array}$ & $\begin{array}{l}\text { This technology can } \\
\text { be used to improve } \\
\text { maintenance } \\
\text { efficiency by } \\
\text { automatically } \\
\text { programming } \\
\text { various park } \\
\text { features, such as } \\
\text { irrigation, lighting, } \\
\text { and trash collection. }\end{array}$ \\
\hline
\end{tabular}




\section{Discussion}

The smart landscape approach was the main concepts that have been used in the revitalization program for the three analyzed historical parks. The stakeholders' participation was the main reason of creating a useful open public space that reflects directly the visitor's interests and needs. Smart landscape approach requires monitoring and post occupancy evaluation together with stakeholder's feedback to develop successful programs that respond to community change and the different preferences of future generation. Smart technologies that are connected to the Internet of things (IOT) can facilitate the procedures of data collection after park operation and help parks managers in taking the better and fast decisions for the park redevelopment programs with the lowest cost. A detailed study of the park infrastructure is essential to help in selecting which technology can fit in the historical park without destroying its historical value. Moreover, Smart technologies can also be used to revitalize the cultural value of the historical monument that may exists in the area of historic park like in the case of Los Angeles State Historic Park.

\section{Conclusion}

City public parks are valuable resources for improving the general human health by providing large green spaces that are used to spend time in connection with the nature as well as providing physical, social, educational and cultural activity. Historical parks can present an asset for the city, but some times they are underutilized especially in developing countries. In general the renovation, conservation and revitalization of such historical parks cost a lot and makes pressure of the government as the main responsible of the historic public gardens. The governments of developing countries may suffer from providing the needed funds for the revitalization projects. The Smart approach provides a great opportunity for reducing pressure on the governments for the revalorization and maintenance costs. It also get citizens and stakeholders involved in the renovation and conservation program which may guarantee the success of the park revitalization as it will reflect the visitors needs and will be updated with the changes of future generations.

\section{REFERENCES}

[1] C. Brandis , 2018. How Smart Parks Revitalize the Urban Park experience. Retrieved 21-2-2019 available at: https://blog.aeris.com/neo/how-smart-parksrevitalize-the-urban-park-experience

[2] L. Loures, R. Santos \& T. Panagopoulos. 2007. Urban Parks And Sustainable City Planning -The Case Of Portimao, Portugal. Wseas Transaction On Environment And Development, Issue 10, Volume3. P.171-180.

[3] J. A. Sayer, et al. 2016. Measuring the effectiveness of landscape approaches to conservation and development. Sustain Sci, Sringer. Japan.

[4] N. Gupta, A. Gupta. 2017. Re-development of Urban Park, Bagh-E-Bahu, Jammu (J\&K) by Using Energy Efficient Landscape Technique. International Conference-Alternative and Renewable Energy Quest, AREQ 2017, Spain.

[5] E. Truch, J. Sutanto. Febrauary 2018. "Smart Parks Bringing new technologies to national parks and urban green spaces". Management Science Department,Lancaster University Management School, Lancaster. UK. Retrieved: 1 October 2019 Available at: http://www.connected.community/smart-park. 
[6] M. E. Burstein. "Smart Parks: A Toolkit". The Luskin Center for Innovation is based in the UCLA Luskin School of Public Affairs. Retrieved: 1 October 2019 Available at: https://innovation.luskin.ucla.edu/sites/default/files/ParksWeb020218.pdf

[7] Boulognerskogen - restoration of an historic park. Retrieved: 8 October 2019. Available at: https://landezine-award.com/boulognerskogen-restoration-of-anhistoric-park/

[8] S. Berjman. 2001/2002. Historical Parks and Cultural Landscapes at Risk. ICOMOs-IFLA International scientific committee of historic gardens-cultural landscape. Argentina. Retrieved 30 September 2019. Available at: https://www.icomos.org/risk/2001/gardens.htm

[9] Berlin Tourismus \& Kongress Gmb. Tiergarten: Berlin's green lung. Retrieved 15 October 2019. Available at: https://www.visitberlin.de/en/tiergarten

[10] World Monuments fund. 2017. Gaslight and gas Lamps of Berlin, Retrieved 15 October 2019. Available at: https://www.wmf.org/project/gaslight-and-gas-lampsberlin

[11] ICOMOS-IFLA Document On Historic Urban Public Parks Adopted by the 19th ICOMOS General Assembly, New Delhi, India, 15 December 2017, Retrieved 15 October 2019. available at: https://www.icomos.org/images/DOCUMENTS/Charters/GA2017_6-32_HistoricUrbanPublicParks_EN_adopted-15122017.pdf

[12] R. Rosenzweig and E. Blackmar, 1992. "The Park and the People, A History of Central Park, Ithaca and London", Cornell University Press, pp. 623

[13] A. Ponte, 1991. "Public Parks in Great Britain and the United States: From a Spirit of the Place to a Spirit of Civilization", In the Architecture of Western Gardens, Cambridge: MIT Press, pp. 373

[14] N.T. Ne City of Ashland. 2019. Master Plan for Lithia Park. Retrieved 15 October 2019. Available at: http://www .ashland.or.us/Page.asp?NavID=14077

[15] wton, 1971. "Design on the Land Cambridge", Harvard University Press, pp.271.

[16] American Planning Association. Lithia Park: Ashland, Oregon. Retrieved 15 October 2019.

Available

at: https://www.planning.org/greatplaces/spaces/2014/lithiapark.htm.

[17] K. Mendelson. November 2009. Historic Public Gardens to Visit: Oregon. Retrieved 15 October 2019. Available at: http://www.halcyon.com/tmend/gardensOR.htm

[18] City of Ashland. 2019. Master Plan for Lithia Park. Retrieved 15 October2019. Available at: http://www.ashland.or.us/Page.asp?NavID=14077

[19] Ashland Parks Foundation . Retrieved 15 October 2019. Available at: http://www .ashlandparksfoundation.com/Page.asp?NavID=21 